\title{
Development, democracy and corruption: how poverty and lack of political rights encourage corruption
}

\author{
NATASCHA S. NEUDORFER \\ Geschwister-Scholl-Institut for Political Science, Ludwig-Maximilians-Universität München, Germany \\ E-mail: Natascha.Neudorfer@gsi.uni-muenchen.de
}

\begin{abstract}
On average, higher per capita income comes with lower corruption levels. Yet, countries like Mexico, Libya and Saudi Arabia are relatively wealthy but experience comparatively high corruption levels. Simultaneously, countries like Madagascar or Mozambique (in the 1990s) combine poor economic development with a low level of corruption. I propose that the two most common variables in corruption research - wealth and democracy - are mutually conditional: economic development brings about a larger (and stronger) middle class that demands public goods from the government. However, citizens' ability to influence governmental decision-making varies by political regime type. In democracies, citizens are, on average, more successful in demanding goods from the government than in autocracies. Using a large- $\mathrm{N}$ approach (up to 139 countries, 1984-2006), the analysis finds robust empirical support for the proposed conditional effect.
\end{abstract}

Key words: accountability, corruption, development, governance, middle class

\section{Introduction}

Economic development (e.g. Sandholtz and Koetzle 2000; Chang and Golden 2007) and democracy (e.g. Treisman 2000; Tavits 2007) have been the two most frequently analysed variables in the empirical causes of corruption research. Both are commonly found to decrease corruption. However, we observe that some rather wealthy countries (e.g. Mexico, Libya and Saudi Arabia) have higher levels of corruption than poorer countries (Madagascar or Mozambique in the 1990s). At the same time, some democracies (Honduras, Panama, Bolivia, Russia, Niger) experience relatively more corruption than autocracies (USSR, Niger, Albania or Bulgaria all in the 1980s).

This paper argues that both political participation and a country's wealth are conditional in their effect on corruption. Extensive economic 
development needs innovation and therefore education - companies need educated workers for further industrial growth, which creates a demand for the public good "education" from the government. However, the political structure crucially determines whether the government gives in to these demands: in democracies, citizens - as voters - can demand goods from the government through elections. In autocracies, however, citizens have a hard time demanding anything from their government. Still, even autocratic rulers cannot completely ignore their people's wishes and, therefore, as wealth increases, the government should grant at least some public goods. Likewise, democratic rights are more likely to limit corruption levels in rich countries with educated and informed voters who demand public goods from the government than in poor countries with less-informed voters who demand little spending on public goods.

The empirical analysis departs from the replication of a model by Gerring and Thacker (2004) who find empirical support for a decreasing influence of wealth and democracy on two operationalizations of corruption in a cross-section of 105 countries. This article then includes an interaction term into Gerring's and Thacker's original cross-sectional analysis. In the next step, I test the postulated conditional hypothesis with my own time-series cross-sectional data of up to 139 countries from 1984 to 2006, including control variables from Gerring's and Thacker's replicated study. Additionally, the empirical analysis is put to a rigorous robustness check.

Results show that economic development and democracy indeed conditionally affect corruption. Whereas nearly all corruption research uses economic development as an explanatory factor and a substantive number of studies control for democracy, my article is, to my knowledge, the first to provide an argument for such a conditional effect and its micro-foundation, thereby contributing to theoretical development in this research area. The inclusion of an interaction term in the replication of one landmark study, as well as testing an extensive data set, provide strong and robust empirical support for the argument: wealth and democracy reduce corruption but their effects are conditional on each other. Neglecting the conditionality of these variables leads to an upward bias of both the effect of economic development in autocracies and the effect of democratic institutions in poor countries.

\section{Definitions of corruption}

When talking about corruption, researchers have varying understandings of the concept. Thus, the first question to answer when researching the causes of corruption is what kind of corruption the research is analyzing. Generally, the main distinction is drawn between two types 
of corruption: Petty or low-level corruption and grand or high-level corruption (Tanzi 1998; Husted 1999; Swamy et al. 2001; You and Khagram 2004; Rose-Ackerman 2006; Fritz 2007; Treisman 2007; Kolstad and Søreide 2009). Petty corruption classifies all corruption that involves citizens making small graft payments to government officials, such as police officers or civil servants, in return for favours, such as avoiding getting a speeding ticket or receiving a government service, such as a visa, more quickly. Grand corruption, in contrast, qualifies all bribery of interest groups ${ }^{1}$ used to gain influence on the decision processes of governments, for example in law-making or with respect to decisions on governmental contracts (You and Khagram 2004). This article focuses on grand corruption and, thus, on how external actors outside the political sphere influence governmental decision-making by means of corrupt actions. I am not investigating bribery in the private sector (within or between firms) or other organizations, but rather what encourages and discourages grafts in the political sphere - grand-scale political corruption.

Definitions of what actions are considered to be corrupt are numerous and commonly describe corruption as an illegal abuse of an official/political position for other means than the benefit of the general public in favour of individual or group benefits. ${ }^{2}$ One example of this is capture in the following definition: "The most popular and simplest definition of corruption is that it is the abuse of public power for private benefit. This is the definition used by the World Bank" (Tanzi 1998, 564). Gardiner $(2007,27)$ summarises Kenneth Gibbons' definition of abusing a position:

- "A civil servant gives a position in his office to a relative rather than to a better-qualified applicant. (Nepotism)

- A political party wins an election and then removes all office-holders who supported the opposition party. (Patronage)

- A legislator owns stock in a mining company, and votes for a bill which will give tax concessions to the company. (Legislative conflict of interest)

- Government bureaucrats use their knowledge and contact to establish a part-time consulting firm which gives advice to private clients. (Bureaucratic conflict of interest)".

${ }^{1}$ The term "interest group" is used in a broad sense. Interest groups can represent different ethnic groups, industries, social groups or interests in society.

2 "Corrupt acts are, in every definition, improper or illegitimate" (Sandholtz and Koetzle 2000, 34). "Here are two possible ways of thinking about corruption. First, as the abuse of the wider interest by narrow interests (the "tragedy of the commons" approach). Second, in terms of the principle that whatever abuses the public good and undermines public faith in the integrity of rules, systems and institutions is corrupting" (Shaxson 2007, 1132). 
Generally, all definitions have in common that corruption takes place between two actors: the bribe-payer (usually an actor outside the political sphere) and the bribe-acceptor (here: an elected or appointed government official). This article defines political corruption as the misuse of an official position for one's own private benefit or the benefit of a certain interest group in society (as defined above).

\section{A Review of the literature}

The large majority of researchers control for economic development (e.g. La Porta et al. 1999; Fisman and Gatti 2002a; Adserà et al. 2003; Kunicová and Rose-Ackerman 2005; Chang and Golden 2007; Gokcekus 2008) - often with a short, rather ad-hoc explanation for the relationship or without specifying the influence on corruption at all. In most articles, researchers find empirical support for a significantly decreasing effect of wealth on corruption. Some researchers provide theoretical reasoning for a decreasing effect of wealth on corruption (Sandholtz and Koetzle 2000; Treisman 2000; Montinola and Jackman 2002; Xin and Rudel 2004).

Two arguments dominate the literature on the influence of economic development on corruption: the role economic development plays in shaping, first, poverty and, second, education levels. The first claim poverty creates financial incentives for corrupt behaviour: In poor countries, the "marginal value of money" (Sandholtz and Koetzle 2000, 36) is substantially higher than in rich countries. This argument follows the Weberian argument that economic development is a prerequisite to make government officials abide by the law (Xin and Rudel 2004). Montinola and Jackman provide a slightly different argument for government officials whose "higher wages in the public sector are expected to lower the incidence of corruption by reducing incentives to engage in corrupt behaviour and by increasing its costs" (Montinola and Jackman 2002, 155). A highly paid government official will lose her high income if she is convicted of corrupt behaviour. Her poorly paid colleague, however, has little to lose from a conviction. Experimental studies confirm that increasing wages decreases the corruptibility of public officials (van Veldhuizen 2013).

The second argument proposes that economic development leads to higher levels of education and literacy, which increase the potential for government officials to be uncovered (Treisman 2000). "A richer country will be able to devote more resources to the detection and prevention of corruption. In addition, the increased education and literacy that development brings will increase the likelihood that an act of 
corruption will be discovered and punished" (Elbhanasawy and Revier 2012, 311). ${ }^{3}$ The vast majority of empirical studies on the influence of wealth on corruption find a decreasing effect (Sandholtz and Koetzle 2000; Treisman 2000; Montinola and Jackman 2002; Xin and Rudel 2004).

As for the relationship between democracy and corruption, mainly three areas of argumentation can be separated: political competition (as a means to encourage control), political rights (as a means to empower voters) and transparency (as a means to make information on corrupt interactions available to the public). As for the empirical results, various studies find empirical support that democracy or democratic traditions reduce the level of corruption in a country (for instance, Sandholtz and Koetzle 2000; Treisman 2000; Lederman et al. 2005; Tavits 2007).

Political competition creates institutional settings that allow a voter to choose between parties and therefore deselect politicians from office (Montinola and Jackman 2002). Montinola and Jackman (2002) outline two paths through which political competition can reduce the level of corruption: "First, the freedom of information and association characteristic of democracies helps monitoring of public officials, thereby limiting their opportunities for corrupt behaviour. Second, the possible turnover of power in democracies implies that politicians cannot always credibly promise that particular laws and regulations will continue in the future". A related aspect is that, in democratic countries, the regular intervals for elections put politicians under the hazard of losing an election and thereby losing office (see, for instance, Pellegata 2013).

Political rights capacitate voters to control politicians and in so doing increase the risk for politicians to be punished for their corrupt action (see Sandholtz and Koetzle 2000; Treisman 2000; Lederman et al. 2005; Tavits 2007; Bhattacharyya and Hodler 2010). In democracies, institutional (e.g. the opposition) or non-institutional (e.g. the media) settings supply information to voters. Voters can make informed decisions based on that information. In autocracies, the information provided to voters is usually more limited and biased (through propaganda) in comparison with democracies. Hence, also in autocracies, the level of corruption varies: personalistic autocracies are on average more corrupt than party or military dictatorships (Chang and Golden 2010).

\footnotetext{
${ }^{3}$ Various papers highlight the importance of the level of education in determining the level of corruption, such as Uslaner and Rothstein (2012) or Lindstedt and Naurin (2010, 304): "The higher the level of education, it can be assumed, the stronger the capacity of people both to access and process information from the media and public records, and subsequently the greater the chances for publicity".
} 
Transparency in the form of, for instance, the freedom of the press is another causal aspect of the level of corruption. ${ }^{4}$ Lindstedt and Naurin (2010) take the research on the relationship between transparency and corruption further by also arguing that the effect of transparency on corruption is conditional on the educational level of voters, availability of different media and electoral democracy: “... we therefore expect interaction effects between transparency and the conditions for publicity (measured by the level of education and media circulation) and between transparency and political (electoral democracy) and legal (rule of law) accountability institutions" (Lindstedt and Naurin 2010, 307).

Various case studies for specific countries (i.e. India) ${ }^{5}$ further support that political institutions play an important role in determining a country's level of corruption.

A different part of the literature ignores theory and focuses only on the empirical analysis of the influence of wealth and democracy by using extreme bounds analysis. For economic development, both Treisman (2007) and Serra (2006) discover consistent empirical support for a decreasing effect on corruption. However, results concerning political rights differ. Both provide evidence that democratic states are associated with a low level of corruption, but Treisman points out that this relationship might not be linear. Pellegata (2013) outlines theoretically and shows empirically that the effect of democracy on the level of corruption is nonlinear. For democratic tradition, Treisman (2007) does not find support for the effect while Serra (2006) finds a highly significant relationship.

This article contributes to the literature by bringing the two factors - economic development and political accountability - together both theoretically and empirically. Combined, they explain more cases than each factor on its own. Additionally, I outline a causal mechanism for the proposed conditional effect.

\section{Theory and hypothesis}

Corruption is the transaction of goods or services between the public and the private sector. In every society, politically external groups want to influence political decision-making for their interests, which usually means gaining material or immaterial benefits from the government's decisions.

${ }^{4}$ Brunetti and Weder (2003) found empirical support for a decreasing effect of a free press on the level of corruption.

5 “ (...) $[\mathrm{T}]$ he steady decline noticeable in the performance of the major institutions of governance and administration in India is symptomatic of the entrenchment of corrupt practices and erosion of morality at the behest of private and personal gain among the politically and economically powerful sections" (Chatterjee and Roychoudhury 2013, 396). 
Apart from the direct corrupt interaction between government officials and interest groups, there is a third important actor in society - the voter. For each of the three types of actors (government, interest group and voter), corrupt behaviour involves costs and/or benefits. All three parties can choose actions that increase or decrease the costs and benefits of corruption. The following paragraphs will outline in more detail the interests and preferences of the actors.

\section{Government, voters and interest groups}

Politicians pursue electoral victory (Downs 1957). Electoral success keeps them in or brings them into office, and for electoral success, they need support from the electorate. In autocracies, politicians also desire to stay in office. Although they do not face democratic elections, autocrats cannot survive without support - at least a large part of the "elite" needs to support the autocratic government (Bueno de Mesquita et al. 2003). The regime type determines whether the group that secures survival in office is small (autocracies) or large (democracies).

Incumbents respond to this incentive structure by choosing an optimal mix of policy instruments. Broadly speaking, we can distinguish between the provision of public and private goods. The larger the group of people determining political survival and thus exerting an influence on politics, the more a government is inclined to buy support by providing public goods (Bueno de Mesquita et al. 2003).

Generally speaking, private goods are more prone to corruption than public goods. By definition, private goods benefit a particular group (Bueno de Mesquita et al. 2002). To increase their benefit, interest groups can try to buy political decisions through bribes. For instance, the car industry (group in society) benefits from low taxation on car sales (private goods). This benefit for the car industry could be increased through an even lower level of taxation. The car industry might try to influence government's tax decisions in favour of a tax cut by offering a bribe that is paid in return for growing profits from more car sales. In contrast, public goods are less prone to corruption because their benefits pertain to a large group in society. The benefits do not apply to a single interest group that might be willing to pay a bribe for more public goods.

Bueno de Mesquita et al. (2003) claim that the specific set of private and public goods offered by political leaders depends on the needs and desires of the winning coalition, the selectorate and the leadership. They view a variety of goods to be public goods but distinguish core public goods from general public goods. Civil liberties, transparency and political rights belong to the former category and so do peace and prosperity (Bueno de 
Mesquita et al. 2003, 179). According to the authors, these goods have in common that all people have an interest in their provision. The provision of general public goods (comprising, for example, education, health care and social security), they believe, is more sensitive to personal needs and tastes, which allows for more variation both within and across societies (Bueno de Mesquita et al. 2003, 186). It is this broader view on public goods that is the definition I use when referring to public goods. Hence, when I talk about the middle class demanding more public goods, I refer to these general public goods. Whereas these public goods are characterised as nonexcludable, nonrival goods, private goods - such as rents for supporters of the government, certain tax policies or subsidies and tariffs - are both excludable and rival (Bueno de Mesquita et al. 2003, 29).

Voters are interested in the government representing their interests, and they prefer to vote for the party or politician that promises to maximise their benefits (Downs 1957). Governments want to stay in office (Downs 1957; Bueno de Mesquita et al. 2003). For governments, corrupt behaviour can be variably dangerous for political survival: in countries where the office depends on support from a large group in society (for instance, in democracies), corrupt behaviour bears the risk of losing the next election. Corrupt politicians might fail to be reelected, because they obviously prefer their private benefits and those of a small group over the benefits of the society as a whole. Granting favours to small groups, such as a tax cut limited to a specific group, reduces financial leeway for public goods. Once the government needs to win support from a majority through the provision of public goods (in democracies), corrupt behaviour might well result in being ousted from office. In contrast, governments in an autocratic society do not have to win the support of the majority. Their power depends on a much smaller group, such as the military or another "elite" group. Providing private goods for them ensures their continued support and the incumbent's office.

One might object that corrupt politicians regularly get reelected. ${ }^{6}$ Research in this area, though, would partly disagree. On average, corruption does hinder the chances of getting relected into office (Ferez and Finan 2008). Media attention strengthens this effect (Ferez and Finan 2008) or conditions the effect of corruption on electoral success: "We find that the incumbent's vote loss after a corruption scandal can rise to $14 \%$ when we consider cases in which the incumbent has been charged with corruption

\footnotetext{
6 "A typical example is Italy's Silvio Berlusconi, who, despite a score of judicial inquiries accusing him of a wide range of crimes, was elected Prime Minister in 1994 and again in 2001. Unfortunately, as much as Berlusconi may be an extreme case, it is far from an isolated one" (Manzetti and Wilson 2007, 950).
} 
and press coverage has been extensive" (Costas-Perézet et al. 2012, 470). Along the same lines, Chang et al. $(2010,177)$ find “(...) that electoral retribution for allegations of criminal behavior by national legislators hinges on the dissemination of relevant information by the mass media". Other conditioning effects of corruption scandals on electoral outcomes could include societal conditions, such as weak government institutions (Manzetti and Wilson 2007) or the state of the economy. ${ }^{7}$

In democracies, freedom of speech and press are usually part of the foundation of their democratic institutions. Hence, in democracies, one crucial conditioning factor for corruption scandals to play a role in electoral outcomes - the media - is already accounted for. In the same manner, this paper already addressed economic circumstances that play a role in corruption scandals influencing elections. Although corruption scandals may not always play a role in elections, they play a role in democracies. Further, I conclude from the literature that the effect of corruption scandals in democracies might be weaker when economic conditions in the country are good.

\section{Economic development and corruption}

The argument for a negative effect of wealth on corruption is quickly summarised. Economic development leads to a higher demand for public goods and consequently reduces the money available for private goods and rents. ${ }^{8}$ The changed demand is determined by two factors: the emergence of a middle class and a change in demand from businesses. Past research by Andersen and Curtis $(2012,135)$ hypothesised that, when the income of citizens rises (through, for instance, a higher GDP per capita), more people identify with a higher class. Their descriptive and regression results support that higher economic development is associated with higher class identity. The following paragraphs explain in more detail how and why the demand for public goods changes as a country's wealth increases.

Economic development creates, enlarges and strengthens one particular social class in society - the middle class. Whereas in poorly developed economies the majority of citizens work in unskilled jobs, a developed economy provides more jobs that require at least some education. ${ }^{9}$

\footnotetext{
7 “(...) [W] show that individuals facing bad (good) collective economic conditions apply a higher (lower) penalty to presidential approval for perceived political corruption" (Zechmeister and Zizumbo-Colunga 2013, 1190).

${ }^{8}$ The government usually spends the budget for public and private goods. As the government budget is, on average, (more or less) fixed, higher spending for one good will result in lower spending for the other good.

9 "I find that the increase in investment by Chilean manufacturing plants could partially explain the growing demand for skilled labor in Chile during the 1980" (Pavcnik 2003, 313).
} 
Skilled employees, however, are not only more educated, but also have a higher salary than their unskilled counterparts. With a salary above the subsistence level, middle class citizens get involved in politics and try to hold their government accountable. One consequence is, for instance, that middle class voters demand that their government spend money on public goods (such as "education"), and they are now able to control whether this demand is fulfilled or not. ${ }^{10}$ Does the middle class really change something in society? Loayza et al. $(2012,441)$ argue and show that when "(...) the size of the middle class increases, social policy on health and education becomes more active, and the quality of governance regarding democratic participation and official corruption improves".

Second, the demand for public goods increases in developed economies because companies also demand public goods, such as education and infrastructure, in order to expand. Business leaders can successfully demand these public goods not only because they are voters themselves but also because they employ other voters and can (to some extent) influence their views on politics and their demands for the provision of public goods. The more important a company, the stronger its influence on the government and its demand for public goods. To generate more and new areas of profit, enterprises need to innovate. To increase innovation, companies need educated and creative people. Companies therefore demand the public good "education" from the government.

Critics might argue that business leaders are exactly the actors identified above to be the bribepayers to the bribe-acceptors (government officials). This is correct: business leaders can both act in the area of corruption and in the area of demanding public goods. The demand for both public and private goods is meant to increase their personal benefit. Demanding private goods is, arguably, the more direct and profitable way of rent-seeking, but it

10 This argument can be backed up with several arguments by other researchers, as well as through historical evidence as outlined by Uslaner and Rothstein (2012). Uslaner and Rothstein (2012) summarise various different arguments in the literature as well as their own reasoning as to why education plays a crucial role in determining the level of corruption in a country. Among others, the arguments are that "a state that establishes broad-based free education is sending out such a very strong signal about being committed to universalism, fairness and impartiality to its citizens which is likely to increase political legitimacy" (Uslaner and Rothstein 2012, 8). Or: "A second theoretical argument for why universal education should be important has to do with the importance of literacy and mass-media for curbing corruption. A free press with a broad circulation is important for curbing corruption (Adsera et al. 2000)" (Uslaner and Rothstein 2012, 7). The empirical analysis of Uslaner and Rothstein (2012) supports the argument that historical education levels (mean school years 1870) play a role in determining the level of corruption in 2010. ["Our main result is that of the importance of 'long historical trajectory', that what happened 150 years ago in a country's system of education greatly impacts its contemporary level of corruption” (Uslaner and Rothstein 2012, 37)]. 
does not exclude the possibility of seeking benefits by requiring public goods. ${ }^{11}$

\section{Economic development, accountability and corruption}

The size of the middle class and the influence of companies only determine the demand for public goods but not their actual provision by the government. The government might take into account the relative size of the group demanding public goods when deciding on the distribution of public spending. Yet, voters and companies can demand public goods far more successfully from the government if they can directly influence who is in power. In democracies, voters and companies can influence the government directly through voting and other official channels of participation in the decision-making process. Policy-makers need to satisfy voters' demands for public goods to get (re)elected (as outlined above). If neither the people nor businesses can fully influence the government (as is the case in autocracies), a relatively larger middle class with stronger companies in a more developed economy will not necessarily result in the provision of more public goods. The impact of economic development on political corruption is, therefore, highly dependent on how much of a say people and businesses have in how their country is governed.

Imagine a country where the government's survival in office is nearly exclusively dependent on a very small number of people (e.g. an autocracy run by a few elites, a military junta, etc.). Even though the middle class might grow very large and companies might become influential in society, their actual ability to (threaten to) throw the government out of office remains rather weak. ${ }^{12}$

In contrast, suppose that a country's government strongly relies on the support of an electoral majority (as in democracies). If the middle class and businesses gain size and strength in this society, political parties also need to attract voters from this part of the selectorate to win elections. Governments can secure support from this group by providing the demanded public goods. Hence, because they have influence on who is in power, the middle class and businesses have a far more direct and successful way of demanding public goods from the government in democracies than in autocracies.

Thus, democratic institutions condition the effect of economic development on corruption: in democracies, we expect a larger share of the middle class to reduce corruption more strongly than in autocratic systems.

11 "The rich, as a class or as interest groups, can use legal lobbying and political contributions or bribery (grand political corruption) to influence lawmaking processes. The rich, as interest groups, as firms, or as individuals, may use bribery or connections to influence law-implementing processes (bureaucratic corruption) and to buy favorable interpretations of the law (judicial corruption)" ( You and Khagram 2005, 138).

12 Still, governments will probably satisfy part of the demands for public goods to prevent large-scale unrest. 
This conditionality also works the other way round: democratic institutions limit corruption more strongly in economically advanced societies than in poor countries. Compared with people living in poverty, voters in rich societies have higher average literacy and levels of education (Treisman 2000), better access to information and, as outlined above, demand more public goods from the government. Therefore, they can make more use of their democratic rights to, among other actions, combat corruption in the political system. Voters in poor countries lack the information needed to punish corrupt politicians and have weaker preferences for general public goods spending. In other words, in a democratic regime, a small middle class can exert little pressure on the government to provide more public goods and to abstain from rent-extraction. A large middle class, on the contrary, is very powerful in demanding more public goods from the democratic government.

The overall argument for democracy, wealth and the interaction of the two can be summarised as follows: Democratic institutions constitute the conditions under which voters can more successfully demand public goods because they have a stronger say in electoral outcomes than in autocracies. More economic development brings up (and strengthens) a new social class in society, namely, the middle class. Together with businesses, they ask for more public goods from the government and thereby can change its spending behaviour as fewer financial resources are available for private goods. As private goods are more prone to corruption, the corruption level should fall with a growing demand for public goods. Whether the government indeed meets the demand for public goods depends on the political context (conditionality of the two factors): in democracies, a government satisfies the wishes of voters more often than in autocracies. Hence, the effect of economic development on the level of corruption is conditioned by the level of democracy. Likewise, democratic institutions limit corruption more strongly in prosperous countries than in poor countries: economic development stimulates conditions - well-informed voters with a demand for public goods - under which voters can credibly threaten to make use of their democratic rights and punish corrupt officials. In poor democracies, on the other hand, voters demand comparably fewer public goods, and corrupt politicians do not have to fear electoral losses as much as in rich countries because poor voters lack education and information.

\section{Illustrating the argument - Bolivia and China}

In the late 1980s (until the 1990s), Bolivia's economic development slightly improved (from 838 USD per capita to 1,006 USD per capita). ${ }^{13}$ Still, Bolivia at that time was (and to some extent still is) one of the poorest countries in

${ }^{13}$ All data for Bolivia and China are taken from the data set of this analysis if not stated otherwise. 
the world. A large part of the population (mainly Indio) remains poor and income is highly unequally distributed. In the last decade of the 20th century, Bolivian corruption levels changed: while wealth increased somewhat from the late 1980s to the 1990s, corruption decreased - although slightly - from a 4 (medium level of corruption) to a 3 out of $6-6$ being the highest level of corruption. Bolivia certainly is not a highly economically developed country its GDP per capita is only a fraction of the 18,565 USD OECD average seen between 1984 and 2003 (from the data in this analysis). The level of Bolivia's economic development on its own suggests a high level of corruption. Therefore, the economic level alone cannot explain the level of corruption.

During the years of economic progress, a Bolivian middle class emerged that demanded public goods from the government. Without access to political decision-making, such a demand would have been in vain and corruption levels would have remained unchanged. However, a decline in corruption was possible because citizens were able to influence their government. At the end of the 20th century, Bolivia had a relatively high level of political accountability (democracy levels of 9-9.5 with 10 being the highest possible value).

A similar growth in economic development can be observed in China from 1996 to 2003 (GDP per capita rose from 716 USD to 1,209 USD). Many people could now afford a slightly higher standard of living, and a middle class emerged and gained economic weight. However, the abilities of the Chinese people to influence their government and prosecute corrupt behaviour was very limited, with a democracy level of 1.5. Not surprisingly, the corruption level was rather high in China with values between 4 and 5 on a scale with the highest corruption at a 6 .

These two countries, Bolivia and China, which both had a slight improvement in their economic situation, are empirical examples of the importance of the interaction between democracy and economic development.

\section{Economic development, accountability and corruption - bypotheses}

From the theoretical argument and the examples outlined above, I derive the following predictions, which are tested in the empirical analysis below: economic development decreases political corruption more strongly in democracies than in autocracies and democratic institutions improve control of corruption more strongly in rich countries than in poor countries

\section{Research design}

\section{Dependent variable}

Corruption is notoriously difficult to measure. Nevertheless, or because of that, several corruption indicators are available for quantitative research. 
The World Bank (WB; Kaufman et al. 2009) and Transparency International (TI) publish corruption indicators using averaged values of various corruption surveys. ${ }^{14}$ Unfortunately, the WB did not make the indicator available yearly for the first couple of years, ${ }^{15}$ and the TI indicator is calculated using surveys and methods that sometimes change. Both are composite indicators: “(...) composite indexes suffer from having varying definitions. Composite indexes have no explicit definition; instead, they are defined implicitly by what goes into them. The sources used in constructing these composite indexes change over time, so the implicit definition of corruption reflected in the index changes over time. Moreover, the sources used in constructing the indexes vary from country to country in a given year" (Knack 2007, 265).

The model of Gerring and Thacker (2004) is a cross-sectional analysis "only" and uses the corruption perception index (CPI) indicator of TI as a measure of corruption. Because of the cross-sectional nature of the data, the problems related to changes in the method of construction of the CPI do not apply. If one analysed the time dimension of the CPI data as well, changes between years might not reflect changes in the corruption level but rather changes due to the different methods used. I rely on CPI data for the replication of Gerring and Thacker (2004) but use the International Country Risk Guide (ICRG) data for my own extended analysis. The advantage of estimating the interaction with both operationalizations of corruption is that it acts as an additional robustness check. If the results of this analysis hold, we can conclude that the results are not driven by using ICRG instead of CPI data or by the longer time frame.

The ICRG index, published yearly by the Political Risk Services (PRS) Group, allows a better comparison of years (PRS Group 2012). The PRS Group (2012) defines corruption as "form[s] of excessive patronage, nepotism, job reservations, 'favor-for-favors', secret party funding, and suspiciously close ties between politics and business". ICRG data on corruption come from an expert survey:

The ICRG staff collects political information and financial and economic data, converting these into risk points for each individual risk component on the basis of a consistent pattern of evaluation. The political risk

14 The WB index is calculated on the basis of " 31 individual data sources" and takes into account different "views of a large number of enterprise, citizen and expert survey respondents in industrial and developing countries" (http://info.worldbank.org/governance/wgi/index.aspx/ \#home, accessed 1 March 2014).

15 The WB measure of corruption is part of "The Worldwide Governance Indicator (WGI) project" and the data are available for the years 1996, 1998, 2000 and 2002 onwards (yearly). This (and additional) information is available on the WB website: http://info.worldbank.org/ governance/wgi/index.aspx/\#home (accessed 1 March 2014). 
assessments are made on the basis of subjective analysis of the available information, while the financial and economic risk assessments are made solely on the basis of objective data. ${ }^{16}$

Data published by the PRS Group on political risks are used by "over $80 \%$ of the top companies in the world (as ranked by Fortune)". ${ }^{17}$ From 1984 onwards, the PRS Group has published the ICRG corruption indicator yearly for between 81 and 139 countries. The number of observations available for the analysis is, therefore, quite substantial.

The corruption index varies between 0 (highest corruption level) and 6 (lowest corruption level). For the empirical analysis in this paper, the intermediate values of the categories are rounded down or up to integer values. Further, the data are inverted so that 0 now represents a low level and 6 a high level of corruption.

Treisman (2007) points out valid concerns about the employment of panel data in a cross-country time-series analysis because the comparability of changes in corruption levels might be problematic. However, this analysis still uses the time dimension for four reasons. First, testing the hypothesis in time and space is one objective of this analysis. Second, the argument makes predictions on the levels of corruption rather than changes. Third, as the quote from Knack $(2007,265)$ above shows, the issue is particularly problematic when using composite indicators (which the ICRG is not). Finally, the ICRG corruption index has been used as an operationalization of corruption by a large number of researchers (La Porta et al. 1999; Dollar et al. 2001; Swamy et al. 2001; Fisman and Gatti 2002b; Sung 2003; Aslaksen 2007; Gokcekus 2008; Schudel 2008; Bhattacharyya and Hodler 2010; Lindstedt and Naurin 2010).

\section{Independent variables}

Economic development has been one of the most analysed variables in research conducted on the causes of corruption. A common operationalization is GDP per capita (Treisman 2000; Adserà et al. 2003; Treisman 2007). Like Treisman (2007), I use data from the WB, while Gerring and Thacker (2004) use data from La Porta et al. (1999).

The operationalization of democracy can draw on the indicator by Freedom House (Treisman 2000; Gerring and Thacker 2005; Kunicová and Rose-Ackerman 2005; Serra 2006; Treisman 2007) or the Polity project (Gerring and Thacker 2004; Treisman 2007). ${ }^{18}$ Gerring and

\footnotetext{
16 http://www.prsgroup.com/ICRG_methodology.aspx (accessed 1 March 2014).

${ }^{17} \mathrm{http} / / /$ www.prsgroup.com/FAQ.aspx (accessed 1 March 2014).

${ }^{18}$ Alternative measures for democratic institutions or accountability could be the Bertelsmann Stiftung's Transformation Index (BTI) or the Global Integrity data. Both are not used as
} 
Thacker operationalise democratic tradition using the Freedom House or Polity III data. They code a country as having a democratic tradition if it reaches a score of 5 to 10 in two consecutive years, and then they add up the number of years with democratic tradition (since 1900). I operationalise political rights using the Polity IV data set, mainly because the democracy indicator of Polity IV has a wider range (between -10 and +10 ), whereas the Freedom House index has only seven values.

The information on the coding of the variable provided in the Polity IV Project (2009) codebook $^{19}$ supports that this variable is a good operationalization of democracy to test the theoretical argument made in this article. The democracy variable that is required to test the hypothesis needs to measure whether citizens can influence governmental decision-making and control the government. In the project, the coding of democracy is based on three aspects: "One is the presence of institutions and procedures through which citizens can express effective preferences about alternative policies and leaders. Second is the existence of institutionalised constraints on the exercise of power by the executive. Third is the guarantee of civil liberties to all citizens in their daily lives and in acts of political participation. Other aspects of plural democracy, such as the rule of law, systems of checks and balances, freedom of the press, and so on are means to, or specific manifestations of, these general principles". ${ }^{20}$ The polity score used in this analysis combines the scoring on measures of autocracy and democracy and " $(\mathrm{t})$ his variable is a modified version (...) in order to facilitate the use of the POLITY regime measure in time-series analyses". ${ }^{21}$

There are at least two other studies that also use Polity IV as a measure for democracy (Pellegata 2013) ${ }^{22}$ and accountability (Lindstedt and

operationalizations for accountability or democracy in this analysis because of the country coverage they provide and the time frame available at the moment. The BTI excludes all OECD countries, and the Global Integrity data cover a varying sample of roughly 30 countries every altering year. Both indicators have been developed only recently. BTI is available from 2003 onwards and the Global Integrity data from 2004 onwards (except for 2005). See http://www.btiproject.org/index/methodology/and http://www.globalintegrity.org/wp-content/uploads/2013/08/2011_GIR_Meth_Whitepaper.pdf (accessed 15 March 2014).

${ }^{19}$ Codebook available from http://www.systemicpeace.org/inscr/p4manualv2012.pdf (accessed 14 March 2014).

${ }^{20}$ Quotes taken from page 14 of the codebook of the Polity IV project (website address see above).

${ }^{21}$ Quotes taken from page 14 of the codebook of the Polity IV project (website address see above).

22 "The Polity conceptual scheme in fact consists of six component measures that record the key qualities of executive recruitment, constraints on executive authority, and political competition" (Pellegata 2013, 1203). 
Naurin 2010). ${ }^{23}$ For the analysis, the original values of the Polity IV project were transformed into values ranging between 0 and 10 with 0.5 steps. ${ }^{24}$

\section{Control variables}

The analysis includes the following control variables, and the robustness section adds further control variables to Model 4. All control variables significantly affect corruption and contribute to the model fit [measured by Akaike information criterion (AIC), Bayesian information criterion (BIC), adjusted McFadden or count $\left.R^{2}\right]^{25}$

A common political control variable is presidential system, which can be expected to increase corruption (Gerring and Thacker 2004; Kunicová and Rose-Ackerman 2005); only Adserà et al. (2003) find a decreasing effect on corruption. Presidential systems are particularly prone to corruption. Whereas a certain part of election campaigns is paid for by taxpayers, private donors contribute large amounts to these (in some cases, horrendously expensive) campaigns, possibly expecting a political favour in return. As operationalization, I use the Database of Political Institutions (Beck et al. 2010 ) and create a dummy variable ( 1 for presidential systems, 0 otherwise). Gerring and Thacker (2004) call it parliamentarism but distinguish between countries with presidential, semipresidential and parliamentary systems.

Another control variable is the presence of a proportional representation system. Several studies include this variable but the empirical results are inconsistent (Adserà et al. 2003; Kunicová and Rose-Ackerman 2005; Chang and Golden 2007; Treisman 2007). The analysis uses DPI (Beck et al. 2010) data to create a dummy where 1 indicates a proportional electoral system, 0 otherwise. Gerring and Thacker (2004) do not include this control variable.

According to several authors, women are "more trust-worthy and publicspirited than men" (Dollar et al. 2001, 423; see also Swamy et al. 2001; You and Khagram 2004). Women having a more dominant role in society, therefore, is claimed to reduce the level of corruption. A political economy argument focusing on employed women comes to the same conclusion: women in the workforce demand specific public goods - ones different from

23 "Political accountability is measured by electoral democracy, i.e. the degree to which the government is selected in free and fair elections" (Lindstedt and Naurin 2010, 308). "Our main measure of electoral democracy will be Polity's index (...)" (Lindstedt and Naurin 2010, 308).

${ }^{24}$ Such a transformation is also done by other researchers, such as Pellegata $(2013,1214)$ : "For the sake of simplicity, I have transformed the original Polity scale from -10 to +10 to a scale that ranges from 0 to $20 "$.

${ }^{25}$ Very good reasons for including or excluding variables are given by Gerring and Thacker (2004, 309): "The first consideration was conceptual: are there sound theoretical reasons for including a particular control variable? The second was empirical: does this variable exhibit a strong, robust empirical effect on corruption?". 
non-working women or working men, which increases the total demand for public goods and leaves less money available for private goods and, hence, rent-seeking and corruption (Neudorfer forthcoming). Dollar et al. (2001), Neudorfer (forthcoming) and Swamy et al. (2001) control for female participation in the labour force. Gerring and Thacker do not include this variable. I use the WB data.

The operationalization for dependency on natural resources is energy depletion as a percentage of gross national income (GNI), with energy depletion defined by the WB (2013a) as "the ratio of the value of the stock of energy resources to the remaining reserve lifetime (capped at 25 years). It covers coal, crude oil, and natural gas". Energy depletion constitutes a good measure for economic dependency on natural resources, because "the dataset represents the most ambitious and comprehensive attempt yet at estimating the value of natural resource extraction" (de Soysa and Neumayer 2007, 206). Apart from the coverage of countries and years, the variable has the advantage that it incorporates the ratio of natural resources as a percentage of GNI. Treisman (2007) and Ades and Di Tella (1999) use resource exports as operationalization. According to Treisman $(2007,236)$, "Ades and Di Tella (1999) argue that corruption tends to be greater where there are larger economic rents available for bureaucrats to capture. They hypothesize that where the economy is more oriented toward natural resources - and especially the export of these resources - rents and corruption will be higher”. Gerring and Thacker include net energy imports as a percentage of commercial energy use.

The hypotheses and findings on the effect of government consumption on corruption are mixed. Adserà et al. (2003) find that government consumption reduces corruption. Others (Husted 1999; Montinola and Jackman 2002; Gerring and Thacker 2005) propose that government consumption augments corruption. I use data by the WB.

Military expenditure. Fisman and Gatti (2002b) outline that defense programmes offer high possibilities for rent-seeking. I expect military expenditures to increase corruption.

Gerring and Thacker further include Protestant tradition, territorial government and bicameralism, socialist state (present or former) and British legal origin. My analysis also includes Protestant tradition as a control variable. I use data provided by "The World Religion Dataset, 1945-2010" (Maoz and Henderson 2013) to measure Protestant tradition. The variable provides the percentage of Protestants living in a country. As the data are only available every fifth year, I replace the following 4 years with the starting value in the first year. This is based on the assumption that religious affiliation varies only slightly during short 
periods such as 5 years. The advantage of this variable (in contrast to the data provided by La Porta et al. (1999)) is that the variable is not a dummy but measures the strength of Protestant tradition. Past research that included Protestant tradition as a control variable were conducted by, for instance, La Porta et al. (1999), Treisman (2000), Kunicová and RoseAckerman (2005), Gokcekus (2008) and Camaj (2012). ${ }^{26}$

To make the comparison easier, Tables 1 and 2 provide an overview of all variables used by Gerring and Thacker (2004) and myself.

The robustness section adds further control variables to Model 4 of Table 3 to test the sensitivity of the results. The variables cover most of the additional controls used by Gerring and Thacker. These variables are: an OECD dummy variable that equals 1 for countries during their OECD membership, trade as percentage of GDP (WB 2013c), import per GDP (WB 2013b) and law and order (PRS Group 2012).

For descriptive statistics of the variables, see Table A.1. Although the total number of cases used in the analysis eventually drops to around 1,600, the analysis covers more than enough countries and years to make testing in time and space possible.

\section{Empirical analysis: testing the hypothesis}

The dependent variable determines the estimation procedure to test the hypothesis. Gerring and Thacker use OLS regression for their crosssectional analysis of the CPI data. Accordingly, Models 1 and 2 estimate OLS models. The ICRG corruption indicator with its seven discrete values clearly has ordinal measurement level. I estimate an ordered logit regression model. An alternative would be an ordered probit model (see Long and Freese (2006) for possible estimation methods), and the results remain robust when using this slightly different technique (see robustness section). The estimations of Models 3 and 4 report robust standard errors.

Beck et al. (1998) suggest including splines to control for autocorrelation. Although this method was first introduced for binary dependent variables, the same intuition can be applied to ordered logit models. The creation of a dummy variable "corruption change" is necessary. This variable takes on the value 1 if the corruption level changes from one

${ }^{26}$ Historical factors might influence the level of corruption: “(...) that the most relevant lessons lie not in what developed countries are currently doing to control corruption, but rather in what they have done in the past, when their societies more strongly resembled the conditions in today's developing world (Andrews 2008)" (Mungiu-Pippidi 2013, 2). The analysis already includes past corruption levels through the splines. Really backward information on corruption, such as the corruption level 100 years ago, is, to my knowledge, not yet available. Hence, Protestant tradition is the main variable used in this analysis to account for historical factors. 
Table 1. Variables, operationalizations, sources

\begin{tabular}{|c|c|c|c|c|}
\hline & Variable & Analysis & Operationalization & Source \\
\hline $\begin{array}{c}\text { Dependent } \\
\text { variable }\end{array}$ & Corruption & $\begin{array}{l}\text { Present analysis, } \\
\text { Gerring and Thacker }\end{array}$ & ICRG CPI & $\begin{array}{l}\text { PRS Group (2012) Transparency } \\
\text { International }\end{array}$ \\
\hline $\begin{array}{l}\text { Explanatory } \\
\text { variables }\end{array}$ & $\begin{array}{l}\text { Democracy and democratic } \\
\text { tradition }\end{array}$ & $\begin{array}{l}\text { Present analysis, } \\
\text { Gerring and Thacker }\end{array}$ & $\begin{array}{l}\text { Democracy score years a country has } \\
\text { been a democracy }\end{array}$ & $\begin{array}{l}\text { Polity IV Project (2009) Freedom } \\
\text { House, Polity III }\end{array}$ \\
\hline & Economic development & $\begin{array}{l}\text { Present analysis, } \\
\text { Gerring and Thacker }\end{array}$ & $\begin{array}{l}\text { GDP per capita in constant 2,000 USD } \\
\text { Real GDP per capita (ln of average } \\
\text { from 1970-1995) }\end{array}$ & $\begin{array}{l}\text { WB (NY.GDP.PCAP.KD) La Porta } \\
\text { et al. (1999) }\end{array}$ \\
\hline \multirow[t]{10}{*}{$\begin{array}{l}\text { Control } \\
\text { variables }\end{array}$} & Energy dependence & $\begin{array}{l}\text { Present analysis, } \\
\text { Gerring and Thacker }\end{array}$ & $\begin{array}{l}\text { Energy depletion ( } \% \text { of GNI) net } \\
\text { energy imports ( } \% \text { of commercial } \\
\text { energy use) }\end{array}$ & WB (NY.ADJ.DNGY.GN.ZS) WB \\
\hline & Political system & $\begin{array}{l}\text { Present analysis, } \\
\text { Gerring and Thacker }\end{array}$ & $\begin{array}{l}\text { Presidential system dummy } \\
\text { parliamentarism }\end{array}$ & DPI (Beck et al. 2010) own coding \\
\hline & Electoral system & Present analysis & Proportional representation dummy & DPI (Beck et al. 2010) \\
\hline & Women in labour force & Present analysis & $\begin{array}{l}\text { Female labour force as per cent of total } \\
\text { labour force }\end{array}$ & WB (SL.TLF.TOTL.FE.ZS) \\
\hline & Military expenditure & Present analysis & "Military expenditure ( $\%$ of GDP)" & WB (MS.MIL.XPND.GD.ZS) \\
\hline & Protestant tradition & $\begin{array}{l}\text { Present analysis, } \\
\text { Gerring and Thacker }\end{array}$ & $\begin{array}{l}\text { "Percent of protestants" \% of } \\
\text { protestants in population }\end{array}$ & $\begin{array}{l}\text { Maoz and Henderson (2013), CIA } \\
\text { World Factbook }\end{array}$ \\
\hline & Government consumption & Present analysis & $\begin{array}{l}\text { "General government final } \\
\text { consumption expenditure (\% of } \\
\text { GDP)" }\end{array}$ & WB (NE.CON.GOVT.ZS) \\
\hline & Unitary & Gerring and Thacker & $1-5$ scale & Own coding \\
\hline & British legal origin & Gerring and Thacker & Dummy coded 1 for British legal origin & La Porta et al. (1999) \\
\hline & Socialism & Gerring and Thacker & Dummy coded 1 for socialism & La Porta et al. (1999) \\
\hline
\end{tabular}

$\mathrm{ICRG}=$ International Country Risk Guide; $\mathrm{WB}=$ World Bank. 
Table 2. Model specifications

\begin{tabular}{|c|c|c|c|c|c|}
\hline & Variable or operationalization & $\begin{array}{c}\text { Model } \\
1\end{array}$ & $\begin{array}{c}\text { Model } \\
2\end{array}$ & $\begin{array}{c}\text { Model } \\
3\end{array}$ & $\begin{array}{c}\text { Model } \\
4\end{array}$ \\
\hline Dependent variable & $\begin{array}{l}\text { ICRG } \\
\text { CPI }\end{array}$ & $\begin{array}{l}\square \\
\square\end{array}$ & $\begin{array}{l}\square \\
\otimes\end{array}$ & $\begin{array}{l}\otimes \\
\square\end{array}$ & $\begin{array}{l}\otimes \\
\square\end{array}$ \\
\hline $\begin{array}{l}\text { Independent } \\
\text { variables }\end{array}$ & $\begin{array}{l}\text { Polity IV } \\
\text { Polity III, Freedom House } \\
\text { Economic development } \\
\text { Democracy } \times \text { economic } \\
\quad \text { development }\end{array}$ & $\begin{array}{l}\square \\
\square \\
\square \\
\square\end{array}$ & $\begin{array}{l}\square \\
\square \\
\square \\
\square\end{array}$ & $\begin{array}{l}\square \\
\square \\
\square \\
\square\end{array}$ & $\begin{array}{l}\square \\
\square \\
\square \\
\square\end{array}$ \\
\hline Control variables & $\begin{array}{l}\text { Energy depletion } \\
\text { Net energy imports } \\
\text { Presidential system } \\
\text { PR system } \\
\text { Parliamentarism } \\
\text { Women in labour force } \\
\text { Government consumption } \\
\text { Military spending } \\
\text { Unitarism } \\
\text { British legal origin } \\
\text { Socialism } \\
\text { Protestantism } \\
\text { Splines }\end{array}$ & $\begin{array}{l}\square \\
\square \\
\square \\
\square \\
\square \\
\square \\
\square \\
\square \\
\square \\
\square \\
\bigotimes \\
\bigotimes \\
\square\end{array}$ & $\begin{array}{l}\square \\
\square \\
\square \\
\square \\
\square \\
\square \\
\square \\
\square \\
\square \\
\square \\
\square \\
\square \\
\square\end{array}$ & $\begin{array}{l}\bigotimes \\
\square \\
\square \\
\bigotimes \\
\square \\
\square \\
\bigotimes \\
\square \\
\square \\
\square \\
\square \\
\square \\
\square\end{array}$ & $\begin{array}{l}\bigotimes \\
\square \\
\square \\
\square \\
\square \\
\square \\
\square \\
\square \\
\square \\
\square \\
\square \\
\square \\
\square\end{array}$ \\
\hline
\end{tabular}

ICRG = International Country Risk Guide; CPI = Corruption Perception Index.

year to the next, independent of whether it rises or falls. If there is no change, the variable equals zero. The length of persistency is determined using Stata's btscs command (Beck et al. 1998). Splines account for the temporal dependence. Testing Model 4 against a model without splines shows that the hypothesis that the coefficients for the splines are all simultaneously zero must be rejected at a 0.01 level. Including the splines is therefore necessary. The inclusion of the splines models potential temporal dependence.

\section{Empirical results}

First, I present the replication of the model by Gerring and Thacker (2004). Gerring and Thacker (2004) offer models using two different measures of corruption - the WB indicator and the CPI index. I replicate Model 4 of Gerring and Thacker (2004, $306 \mathrm{f}$.), which relies on the CPI index (see Model 1 in Table 3). Next, I include the interaction between democracy and economic wealth (Model 2). 
In Model 3, I test the hypothesis using my preferred data for economic development and political accountability (and the interaction between the two), combined with the control variables of Gerring and Thacker, using a cross-section of countries with data from the year 1995, as in Gerring and Thacker (2004).

Model 4 analyses the full cross-sectional time-series data set with the most common control variables using my operationalizations for all variables (see Table 2 for an overview of the model specifications). I leave out British legal origin, unitary system and socialist party. However, as Model 3 includes all control variables from Gerring and Thacker, there is empirical support for the hypothesis even with these omitted control variables. This is a decision based on the view that smaller models are preferable to larger models. All other control variables included in my main model (Model 4) are very common control variables that are significantly related to corruption and substantially increase the model fit.

\section{Interpretation of the results}

CPI and ICRG take on large values for high levels of corruption such that a positive coefficient in the regression analysis indicates an increasing (worsening) effect on corruption and a negative coefficient reflects an improvement of the level of corruption (corruption decreases).

$R^{2}$ values in ordered probit or logit models are usually rather low and not comparable to the $R^{2}$ in OLS models. ${ }^{27}$ Long and Freese $(2006,112)$ suggest looking at AIC or BIC to compare model fits (outlined for binary choice models). AIC and BIC were taken into account when deciding on the specification of Model 4 of Table 3 to secure the best possible model fit.

The interaction between economic development and democracy reduces corruption in all three models (Models 2 to 4). In Models 2 and 3, the coefficient for the interaction misses the significance level. Yet, the effect of interaction terms on the dependent variable cannot be interpreted as straightforwardly as the effect of a single (unconditional) term: in interactions, the effect of $x$ (i.e. democracy) and $z$ (GDP per capita) on the dependent variable is split up into two coefficients - the single term and the interactive term - and depends on the values of $x$ and $z \cdot{ }^{28}$ Berry et al. (2012, $658)$ suggest looking at whether " $(t)$ he marginal effect of $\mathrm{X}$ is [positive,

\footnotetext{
27 "Unfortunately, low $\mathrm{R}^{2}$ values in logistic regression are the norm and this presents a problem when reporting their values to an audience accustomed to seeing linear regression values" (Hosmer and Lemeshow 2000, 167).

${ }^{28}$ It is noteworthy to point out that because “(...) multiplicative interaction models (...) make the effect of the independent variable $\mathrm{X}$ on the dependent variable $\mathrm{Y}$ depend on some third
} 
Table 3. The effect of economic development and democracy on political corruption: replication, amendment of Gerring and Thacker (2004) and own estimation

\begin{tabular}{|c|c|c|c|c|}
\hline Corruption index & $\begin{array}{c}\text { Gerring and Thacker } \\
\text { Model } 1 \\
\text { CPI } \\
\text { Replication }\end{array}$ & $\begin{array}{l}\text { Gerring and Thacker } \\
\text { Model } 2 \\
\text { CPI } \\
\text { Interaction included }\end{array}$ & $\begin{array}{c}\text { Gerring and Thacker } \\
\text { Model } 3 \\
\text { ICRG (1995) } \\
\text { Amended }\end{array}$ & $\begin{array}{c}\text { Author } \\
\text { Model } 4 \\
\text { ICRG } \\
\text { Own estimation }\end{array}$ \\
\hline GDP p.c. ${ }^{\dagger}$ & $\begin{array}{l}-0.8231 * * * \\
(0.1201)\end{array}$ & $\begin{array}{l}-0.7963 * * * \\
(0.1470)\end{array}$ & $\begin{array}{c}-0.1192 \\
(0.1163)\end{array}$ & $\begin{array}{l}-0.0539 * * * \\
(0.0160)\end{array}$ \\
\hline Democracy & $\begin{array}{l}-0.0227 * * * \\
(0.0054)\end{array}$ & $\begin{array}{c}-0.0131 \\
(0.0306)\end{array}$ & $\begin{array}{c}-0.0485 \\
(0.1075)\end{array}$ & $\begin{array}{l}-0.0576 * * \\
(0.0250)\end{array}$ \\
\hline GDP p.c. $\times$ democracy & & $\begin{array}{c}-0.0011 \\
(0.0036)\end{array}$ & $\begin{array}{c}-0.0053 \\
(0.0127)\end{array}$ & $\begin{array}{l}-0.0041 * * \\
(0.0019)\end{array}$ \\
\hline Presidential & $\begin{array}{l}-0.2959 * * \\
(0.1459)\end{array}$ & $\begin{array}{l}-0.2966 * * \\
(0.1467)\end{array}$ & $\begin{array}{c}0.4838 \\
(0.6729)\end{array}$ & $\begin{array}{l}0.6055 \% * \\
(0.1276)\end{array}$ \\
\hline Proportional representation/plurality system & & & $\begin{array}{l}-1.3897 * * \\
(0.6203)\end{array}$ & $\begin{array}{l}-0.4228 * * * \\
(0.1156)\end{array}$ \\
\hline Energy dependency & $\begin{array}{l}-0.0014 * * * \\
(0.0004)\end{array}$ & $\begin{array}{l}-0.0014 * * * \\
(0.0004)\end{array}$ & $\begin{array}{c}-0.0021 \\
(0.0022)\end{array}$ & $\begin{array}{l}0.0326 * * * \\
(0.0049)\end{array}$ \\
\hline Percentage of women ${ }^{\ddagger}$ & & & $\begin{array}{c}0.0097 \\
(0.0598)\end{array}$ & $\begin{array}{l}0.0200 * * * \\
(0.0073)\end{array}$ \\
\hline Protestant tradition & $\begin{array}{l}-0.0197 * * * \\
(0.0055)\end{array}$ & $\begin{array}{l}-0.0188 * * * \\
(0.0062)\end{array}$ & $\begin{array}{l}-0.0712 * * * \\
(0.0174)\end{array}$ & $\begin{array}{l}-2.2265^{* * *} \\
(0.3295)\end{array}$ \\
\hline British legal & $\begin{array}{l}-0.4073 \\
(0.2804)\end{array}$ & $\begin{array}{c}-0.4135 \\
(0.2824)\end{array}$ & $\begin{array}{c}-0.0422 \\
(0.6543)\end{array}$ & \\
\hline Socialist party & $\begin{array}{c}0.3470 \\
(0.3166)\end{array}$ & $\begin{array}{c}0.3459 \\
(0.3181)\end{array}$ & $\begin{array}{l}-2.0034^{* * * *} \\
(0.7354)\end{array}$ & \\
\hline Unitary system & $\begin{array}{l}-0.1936 * * \\
(0.0859)\end{array}$ & $\begin{array}{c}-0.1924 * * \\
(0.0864)\end{array}$ & $\begin{array}{c}-0.2659 \\
(0.2151)\end{array}$ & \\
\hline Government consumption & & & $\begin{array}{c}-0.0235 \\
(0.0521)\end{array}$ & $\begin{array}{l}-0.0732 * * * \\
(0.0097)\end{array}$ \\
\hline Military spending & & & $\begin{array}{c}-0.0913 \\
(0.1714)\end{array}$ & $\begin{array}{l}-0.0370 * * \\
(0.0164)\end{array}$ \\
\hline
\end{tabular}


Table 3: Continued

\begin{tabular}{|c|c|c|c|c|}
\hline Corruption index & $\begin{array}{c}\text { Gerring and Thacker } \\
\text { Model } 1 \\
\text { CPI } \\
\text { Replication }\end{array}$ & $\begin{array}{l}\text { Gerring and Thacker } \\
\text { Model } 2 \\
\text { CPI } \\
\text { Interaction included }\end{array}$ & $\begin{array}{l}\text { Gerring and Thacker } \\
\text { Model } 3 \\
\text { ICRG (1995) } \\
\text { Amended }\end{array}$ & $\begin{array}{c}\text { Author } \\
\text { Model } 4 \\
\text { ICRG } \\
\text { Own estimation }\end{array}$ \\
\hline Corruptionyears & & & & $\begin{array}{c}0.1915 \\
(0.1816)\end{array}$ \\
\hline _spline 1 & & & & $\begin{array}{l}0.1145^{* * *} \\
(0.0555)\end{array}$ \\
\hline _spline 2 & & & & $\begin{array}{c}-0.0469^{*} \\
(0.0260)\end{array}$ \\
\hline _spline 3 & & & & $\begin{array}{c}0.0031 \\
(0.0044)\end{array}$ \\
\hline Constant & $\begin{array}{c}2.7736^{* * *} \\
(0.8151)\end{array}$ & $\begin{array}{c}2.5684 * * \\
(1.0413)\end{array}$ & & \\
\hline Observations & 105 & 105 & 82 & 1,598 \\
\hline Adjusted $R^{2 \S}$ & 0.79 & 0.79 & 0.23 & 0.20 \\
\hline Count $R^{2}$ & & & 0.65 & 0.44 \\
\hline AIC & & & 177.580 & 4328.867 \\
\hline BIC & & & 218.494 & 4436.397 \\
\hline Method & CS & CS & CS & TSCS \\
\hline Estimation & OLS & OLS & OLOGIT & OLOGIT \\
\hline
\end{tabular}

Robust standard errors in parentheses.

${ }^{\dagger}$ Gerring and Thacker (2004) use the natural log of GDP per capita.

$\ddagger \%$ of women in the labour force.

${ }^{\$}$ Adjusted $R^{2}$ for Models 1, 2 and McFadden's adjusted $R^{2}$ for Models 3 and 4; for Model 3 and 4 GDP per capita divided by 1,000. $\mathrm{AIC}=$ Akaike information criterion; $\mathrm{BIC}=$ Bayesian information criterion; CS = cross-section; ICRG = International Country Risk Guide; TSCS = time-series cross-section.

*Significant at $10 \%$; *significant at $5 \% ; \mathrm{H}^{* * *}$ significant at $1 \%$. 
negative, zero] when $\mathrm{Z}$ is at its lowest value" and when $z$ is at its maximum. Along the same lines, the effect of $z$ on the dependent variable can be analysed by keeping $x$ fixed at the minimum and maximum, respectively (Berry et al. 2012). The fifth proposition is to analyse, according to Berry et al. $(2012,658)$ whether "The marginal effect of each of X and Z is [positively, negatively] related to the other variable" and should look at "as many of the five predictions listed above as possible" (Berry et al. 2012, 659). In what follows, I will outline the interaction effects for Models 2 and 4 of Table 3 based on the first four propositions.

Brambor et al. (2006) show that, in interaction models, the effect of $x$ on $y$ is conditional on a value $z$. Therefore, to simply look at the coefficients is not sufficient: we cannot infer from the sign and the level of significance of a coefficient of the interaction on its effect on $y,{ }^{29}$ and insignificant regression coefficients do not necessarily mean that the effect of $x$ on $y$ or the effect of $z$ on $y$ is insignificant. ${ }^{30}$ Further, “(...) it is perfectly possible for the marginal effect of $\mathrm{X}$ on $\mathrm{Y}$ to be significant for substantively relevant values of the modifying variable $\mathrm{Z}$ even if the coefficient on the interaction term is insignificant" (Brambor et al. 2006, 74). ${ }^{31}$

I use the data of Model 2 to simulate the overall effect of GDP per capita and democracy. Figure 1 presents the results and shows the effect of GDP per capita conditional on democracy (from minimum to maximum) including 95\% confidence intervals. Increasing GDP per capita significantly reduces the level of corruption at all levels of democracy. As for the effect of democracy conditional on GDP per capita, see Figure S.10 in the online appendix. ${ }^{32}$

For further illustration, I include margin plots for Model 2 in the online appendix (Figures S.1a to S.1d). Following the first four suggestions by

variable $Z$ (...) the constitutive term $X$ must not be interpreted as the average effect of a change in $\mathrm{X}$ on $\mathrm{Y}$ as it can in a linear-additive regression model" (Brambor et al. 2006, 72).

29 "It is, therefore, incorrect to say that a positive and significant coefficient on X (or Z) indicates that an increase in $\mathrm{X}$ (or Z) is expected to lead to an increase in Y" (Brambor et al. 2006, 72).

30 "Just as we have come to recognize that coefficients in logit and probit models cannot be interpreted as unconditional marginal effects, we should recognize that the coefficients on constitutive terms in interaction models cannot be interpreted in this way either" (Brambor et al. 2006, 72).

31 "It means that one cannot determine whether a model should include an interaction term simply by looking at the significance of the coefficient on the interaction term. Numerous articles ignore this point and drop interaction terms if this coefficient is insignificant. In doing so, they potentially miss important conditional relationships between their variables" (Brambor et al. 2006, 74).

32 “(...) they have a statistically significant effect whenever the upper and lower bounds of the confidence interval [of the marginal effect] are both above (or below) the zero line" Brambor et al. (2006, 76). 


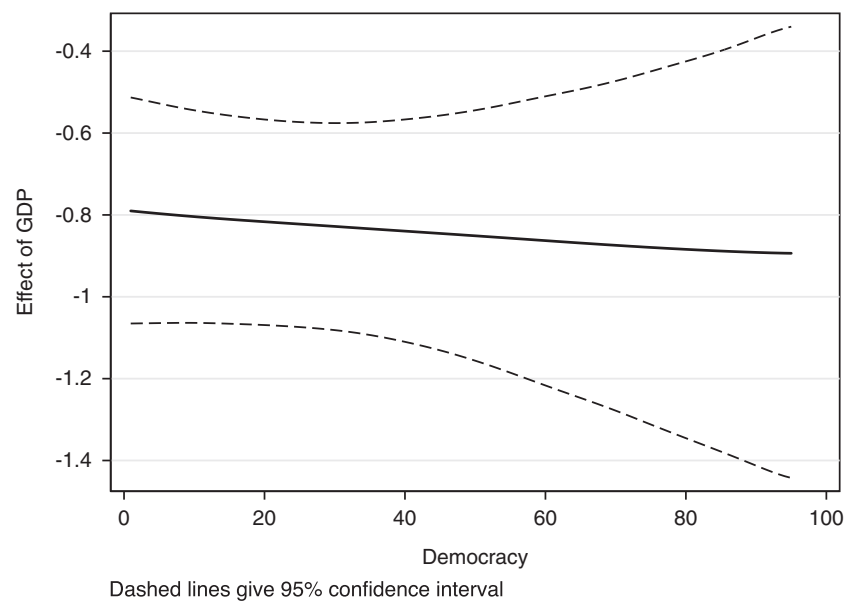

Figure 1 Effect of GDP per capita conditional on democracy for Model 2 of Table 3.

Berry et al. (2012, 658), Figure S.1a looks at varying levels of GDP per capita when democracy (the modifying variable) is kept at its minimum (and at its maximum in Figure S.1b). And, in Figure S.1c, the level of democracy varies while GDP per capita (modifying variable) is at its minimum (and at its maximum in Figure S.1d). In all four figures, higher values of democracy or GDP per capita reduce the level of corruption. However, this effect of democracy is weak when GDP is at its minimum. Moreover, both variables reduce corruption levels more strongly when the respective modifying variable is at its maximum (Figures S.1b and S.1d) compared with its minimum (Figures S.1a and S.1c). Hence, the margins plots support the hypothesis of a conditional effect between democracy and GDP.

Testing the interaction effect using a time-series cross-sectional data set (Model 4) also provides empirical support for a conditionality between economic development and democracy. This model includes a different set of control variables (compared with Model 2), and the decreasing effect of the interaction remains. Model 4 is now further interpreted and its robustness is tested.

I illustrate the effect of the interaction in Model 4 for a low level of corruption (ICRG equals 1) and a high level of corruption (ICRG equals 5). I let democracy vary (between 1 and 10), while economic development is fixed at the minimum (Figures $2 \mathrm{a}$ and $3 \mathrm{a}$ ) and the maximum of GDP per capita, respectively (Figures $2 \mathrm{~b}$ and $3 \mathrm{~b}$ ). In the same manner, I vary GDP per capita from minimum to maximum while democracy is fixed at its minimum (Figures $2 \mathrm{c}$ and $3 \mathrm{c}$ ) and maximum values (Figures $2 \mathrm{~d}$ and $3 \mathrm{~d}$ ). 
(a)

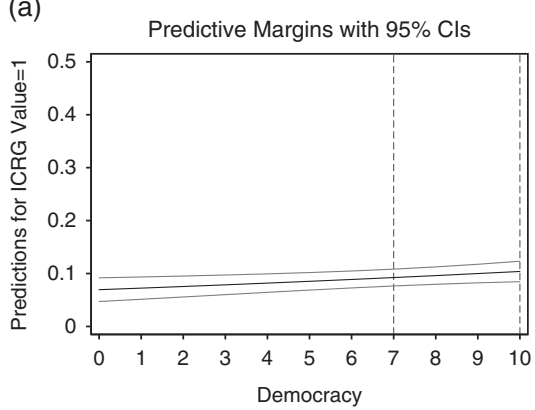

(c)

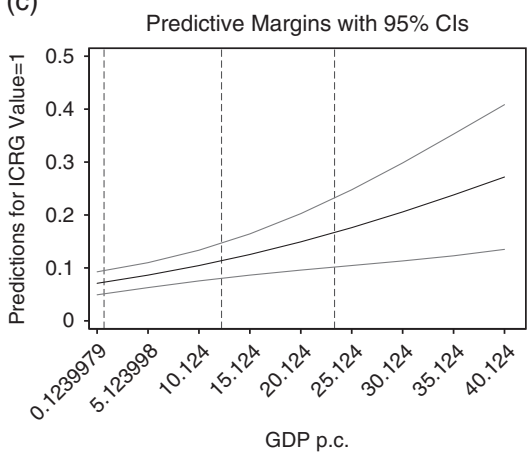

(b)

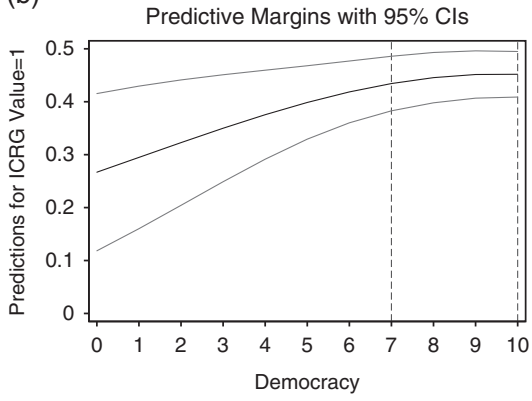

(d)

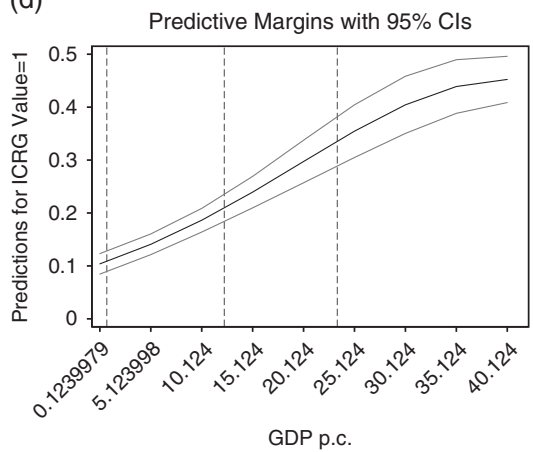

Figure 2 Margins plots for hypotheses based on Model 4 in Table 3. Influence of the interaction effect [GDP per capita (p.c.) and democracy] on a low level of corruption [International Country Risk Guide (ICRG) value 1]. (a) Varying levels of democracy (from minimum to maximum). Vertical lines represent 25 th and 75 th percentile of democracy. GDP p.c. at its minimum. (b) Varying levels of democracy (from minimum to maximum). Vertical lines represent 25th and 75th percentile of democracy. GDP p.c. at its maximum. (c) Varying levels of GDP p.c. (from minimum to maximum). Vertical lines represent 25th, 75th and 90th percentile of GDP p.c. Democracy at its minimum. (d) Varying levels of GDP p.c. (from minimum to maximum). Vertical lines represent 25th, 75th and 90th percentile of GDP p.c. Democracy at its maximum.

Looking at a low level of corruption (Figure 2), the following pattern can be observed: when democratic rights increase, the predicted probabilities for a low level of corruption increase as well (see the upward sloping prediction lines in Figures $2 \mathrm{a}$ and $2 \mathrm{~b}$ ). Yet, the predicted probabilities are much higher (i.e. the effect of democracy is much stronger) and predictions for a low level of corruption increase more quickly (steeper slope) in very wealthy countries (i.e. when GDP per capita is at its maximum, see Figure $2 \mathrm{~b}$ compared with Figure $2 \mathrm{a}$ ). 
(a)

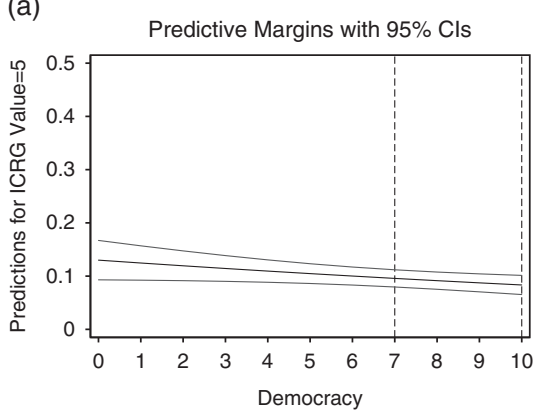

(c)

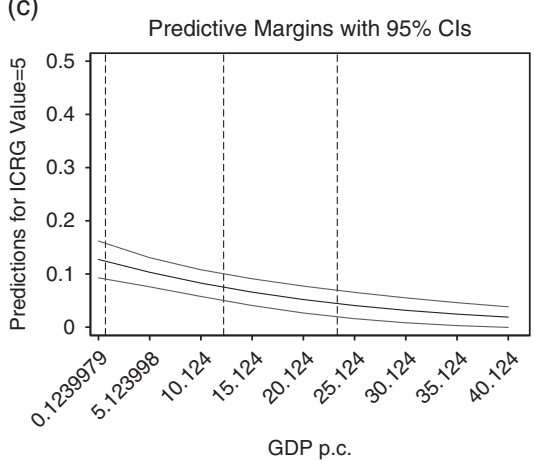

(b)

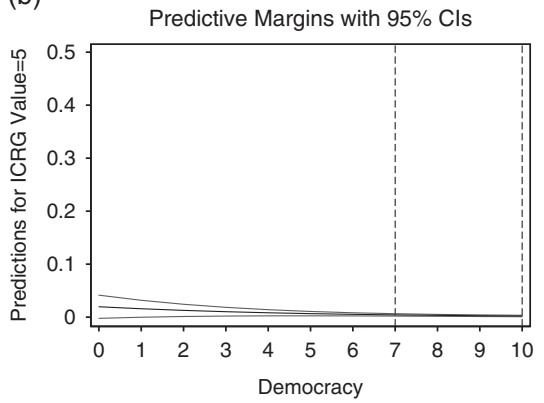

(d)

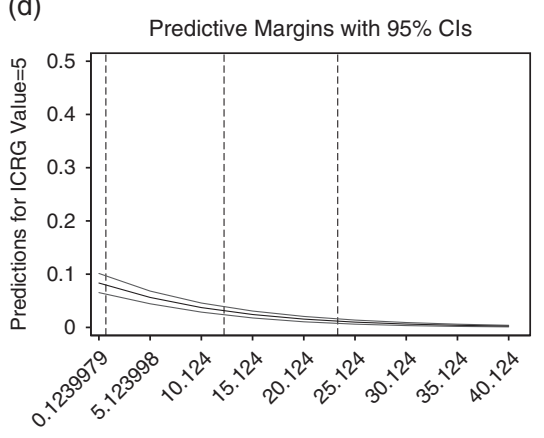

Figure 3 Margins plots for hypotheses based on Model 4 in Table 3. Influence of the interaction effect [GDP (p.c.) and democracy] on a high level of corruption [International Country Risk Guide (ICRG) value 5]. (a) Varying levels of democracy (from minimum to maximum). Vertical lines represent 25 th and 75 th percentile of democracy. GDP p.c. at its minimum. (b) Varying levels of democracy (from minimum to maximum). Vertical lines represent 25 th and 75 th percentile of democracy. GDP p.c. at its maximum. (c) Varying levels of GDP p.c. (from minimum to maximum). Vertical lines represent 25 th, 75 th and 90th percentile of GDP p.c. Democracy at its minimum. (d) Varying levels of GDP p.c. (from minimum to maximum). Vertical lines represent 25 th, 75 th and 90th percentile of GDP p.c. Democracy at its maximum.

In other words, countries with democratic institutions have a higher chance of avoiding suffering from corruption when compared with countries with little or no democratic institutions. However, as predicted by the theoretical argument in this article, democratic institutions are much more effective in wealthy countries than in poor countries.

When varying the level of GDP per capita from minimum to maximum, the interpretation for the interaction effect is very similar: rich countries 
have a higher probability of a low level of corruption than poor countries (positive slope), and their probability is higher and increases more quickly (steeper slope) if these countries also have democratic institutions (see Figures $2 \mathrm{c}$ and $2 \mathrm{~d}$ ). This evidence supports the hypothesis that economic development reduces corruption, but that its effect on corruption is stronger in countries with democratic institutions than autocracies.

Looking at predicted probabilities for a high level of corruption (Figure 3) supports this evidence: rich countries (Figure 3b) have lower and more quickly decreasing predicted probabilities when political rights improve compared with poor countries (Figure 3a). However, the effect is not significant in rich countries with a democracy value between 0 and 1 . When GDP per capita is varied from minimum to maximum, the margin line for highly democratic countries (Figure 3d) is lower and reaches the zero line more quickly than in poorly democratic countries (Figure 3c). In both cases, the effect is not significantly different from 0 at higher levels of economic development (GDP per capita above 40.124 USD, which is equal to or above the 99th percentile). This is as can be anticipated: if our hypothesis is correct, we expect that the predictions for high levels of corruption are zero or very close to zero for high levels of democracy and economic development. In contrast, the predictions for low levels of corruption should be high and significantly different from zero for countries with high levels of GDP per capita and democracy (which is supported by Figures $2 \mathrm{a}$ to $2 \mathrm{~d}$ ).

The margin plots for low and high levels of corruption clearly show a conditional effect of democracy on corruption depending on economic development; if there was no conditional effect, the margin lines would look the same for all varying values of the wealth variable, but they do not. They would only show a shift in the intercept if there were no conditional effect.

As for the control variables, the estimated models allow the following conclusions: presidential systems give mixed results of a decreasing and increasing effect, whereas the literature usually finds an increasing effect (but this is supported by the main model - Model 4). Proportional representation decreases corruption according to my estimations, whereas the findings are mixed in the literature. Energy dependency and a socialist party system allow heterogeneous conclusions for their effect on corruption (but again Model 4 supports the expected effect that energy dependency increases corruption). Women in the workforce increase corruption, which clearly contradicts previous findings. A Protestant tradition, a British legal tradition, as well as a unitary system lower corruption in all estimated models. The effects for the control variables of government consumption are in line with the results of Adserà et al. (2003), whereas for military 
spending, my expectation would have been that it worsens corruption. Instead, it improves control of corruption.

The model relatively successfully predicts real values of actual observations. For example, using the values of the independent variables for Bolivia in 1994, the actual corruption level of 3 is predicted with a probability of 0.4117 , which is the highest probability of all seven categories. ${ }^{33}$ A country with an intermediate level of corruption and a medium level of economic development but a low level of democracy is Morocco. For Morocco in 2002, the actual level of corruption (3) has a probability of 0.3932 , which is the highest probability. The surrounding categories have probabilities of 0.1577 (category four) and 0.2628 (category two), respectively.

\section{Robustness of the results}

Model 4 is subjected to several robustness checks. Following the suggestion by Plümper and Neumayer (2006), a groupwise jackknife (with groups as regions, such as North Africa or Europe) tests the sensitivity of the results. Excluding a region means that there is a higher chance that the coefficients will switch signs than if only one observation or country is excluded. Consequently, excluding regions is a stronger robustness check than excluding only observations (or countries). If the signs of the variables of interest (in this case, the overall marginal effect rather than the single coefficients) remain unchanged, the results are considered to be robust according to Sala-i-Martin (1997).

Several studies include dummies for geographical areas or the OECD (see, for instance, Swamy et al. 2001; Gerring and Thacker 2005; Kunicová and Rose-Ackerman 2005) to account for regional differences in corruption levels. In line with Persson et al. (2003), I expect OECD members to have lower corruption levels. The OECD dummy and the GDP per capita variable are highly correlated $(0.7448)$, and this potential multicollinearity could lead to larger standard errors (as described for OLS models by, for instance, Wooldridge (2008, 523)).

When looking at the groupwise jackknife (Table S.1), as well as when including an OECD dummy (Table S.2), the exclusion of two groups or the inclusion of an OECD dummy changes the signs of the coefficients of GDP per capita (in the case of Asia) and the interaction (in the case of North Africa and the OECD dummy). As outlined above, the sign and significance of the coefficients does not necessarily mean that the effect changes. Therefore, I provide margins plots for the results when excluding the two

\footnotetext{
${ }^{33}$ Category two is predicted with a probability of 0.1549 and category four with a probability of 0.2974 .
} 
groups (North Africa and Asia) and including the OECD dummy. Like for the illustrations of Model 4 in Table 3, I provide plots for a low ${ }^{34}$ and a high level of corruption ${ }^{35}$ to illustrate the interaction effect.

For the results of the excluded regions and the included OECD dummy, the overall conclusions for ICRG value 1 are the same as for Model $4 .{ }^{36}$ For ICRG value 5, the results are slightly different but in favour of the hypothesis: when democracy is at its minimum or maximum (and GDP per capita varies), the effect becomes insignificant more quickly than in Model $4 .{ }^{37}$ Hence, the expected lack of an effect (i.e. an insignificant coefficient) is reached more quickly when excluding Asia and North Africa or including an OECD dummy, which strengthens the support for the hypothesis. When GDP is at its maximum (and democracy varies between minimum and maximum), the effect is never significant (Figures S.5d, S.7d and S.9d). Again, this supports the hypothesis even more than the results of Model 4.

A bootstrap (Table S.3) also supports that the results are robust. Although the signs of the coefficients change, the overall effect stays the same according to the margins plots.

Another check involves the inclusion of additional control variables (results available in the online appendix in Table S.2). Including government stability, an OECD dummy, as well as trade per GDP does not change the signs of the coefficients of the main variables of interest (Models 2, 3 and 4 in Table S.2).

Several researchers point out that political stability (see Tavits 2010, 1258 ) or instability (see Serra 2006, 226) might play a role in causing corruption. Serra (2006) argues that political instability might be related to higher levels of corruption. I use the government stability measure provided by the PRS Group (the same data set providing the ICRG corruption indicator) to account for this potential cause. The main results remain robust when including this variable. The model fit does not substantially increase when including this variable, and therefore the variable is not added to the main model.

Previous literature argues that trade should decrease corruption, as trade encourages competition, thereby reducing opportunities for rent-seeking (see, for instance, Ades and Di Tella 1999; Sandholtz and Koetzle 2000;

${ }^{34}$ ICRG value 1 in Figures S.4a to S.4d for the exclusion of North Africa, Figures S.6a to S.6d for the exclusion of Asia, and Figures S.8a to S.8d for the inclusion of OECD dummies.

${ }^{35}$ ICRG value 5 in Figures S.5a to S.5d for the exclusion of North Africa, Figures S.7a to S.7d for the exclusion of Asia, and Figures S.9a to S.9d for the inclusion of OECD dummies.

${ }^{36}$ ICRG value 1 in Figures S.4a to S.4d for the exclusion of North Africa, Figures S.6a to S.6d for the exclusion of Asia and Figures S.8a to S.8d for the inclusion of OECD dummies.

${ }^{37}$ ICRG value 5 in Figures S.5a to S.5 d for the exclusion of North Africa, Figures S.7a to S.7d for the exclusion of Asia and Figures S.9a to S.9d for the inclusion of OECD dummies. 
Treisman 2007; Camaj 2012). I operationalise a country's trade relations using the amount of trade as a percentage of GDP. The results remain robust.

An additional robustness check is the inclusion of clustered robust standard errors (instead of robust standard errors): again, the results remain robust (Model 5 in Table S.2). Last but not least, I replace the estimation procedure of an ordered logit with an ordered probit model. The results hold and are robust towards this check (Model 6 in Table S.2).

Besides the signs of the coefficients, the estimation in Table S.2 also reports several measures for goodness of fit (such as AIC and BIC). Compared with these robustness models, the main Model 4 in Table 3 provides a good model fit to the data. AIC and BIC do not change very much when adding control variables.

In summary, the empirical results are robust to excluding regions, bootstrapping, different model specifications, different operationalizations of the dependent variable (ICRG and CPI for Gerring and Thacker) and the inclusion of several additional control variables. Some of the robustness tests even make the results stronger.

\section{Conclusion}

This article proposes that wealth and political rights are conditional in their influence on grand political corruption. Economic development decreases corruption because it brings up a new actor in society - the middle class. This class demands public goods, such as education, from the government. The government is, therefore, forced to change its spending behaviour (increase the share of spending on public goods), and less money remains for corruption. How successful voters are in demanding these goods from the government depends on the political situation in the country: the more democratic a country's institutions, the more the government needs to rely on support from the people to stay in office. Hence, the influence of a growing middle class on governmental spending behaviour increases with higher levels of democracy.

Replicating the cross-sectional analysis of one major prior study (Gerring and Thacker 2004) and additionally testing the hypothesis against a sample of over 100 countries covering a time period of more than 20 years, I find empirical support for a conditional effect of economic development and democracy on corruption. Wealthy countries with democratic institutions are less corrupt than wealthy countries with an autocratic system. Likewise, rich democracies are less corrupt than poor democracies. This conditionality also finds support when including Gerring's and Thacker's control variables and when including the conditional effect into one model 
of Gerring and Thacker. My empirical results are significant and robust to various sensitivity tests.

Overall, the empirical findings for a decreasing effect of economic development and democracy on corruption are consistent with the findings of former research (see e.g. La Porta et al. 1999; Adserà et al. 2003; Xin and Rudel 2004; Kunicová and Rose-Ackerman 2005; Chang and Golden 2007). I provide a political economy explanation for and empirical evidence supporting the premise that economic development and political accountability are conditional in their effect on political corruption. The analysis suggests that the inclusion of the conditional effect in empirical models is crucial and ignoring it leads to biased results. Therefore, if a country wants to fight its political corruption, it should encourage economic growth by educating people and strengthening its middle class. However, the decreasing effect will be conditional on the setup of democratic institutions in the country.

\section{Acknowledgements}

The author would like to thank Kristian Gleditsch, Peter John, Benjamin Neudorfer, Thomas Plümper, Laura Seelkopf, Vera Troeger and two anonymous reviewers for comments and suggestions on earlier drafts. Johannes Pöhlmann provided excellent research assistance. This paper is part of a PhD dissertation at the University of Essex, which was partly funded by the Gottlieb Daimler- und Karl Benz-Stiftung, Dr.-Carl-BenzPlatz 2, D-68526 Ladenburg, and by the Economic and Social Research Council, UK. The author thanks the organizations for their financial support that made this project possible.

\section{Supplementary material}

To view supplementary material for this article, please visit http://dx.doi. org/10.1017/S0143814X14000282

\section{References}

Ades A. and Di Tella R. (1999) Rents, Competition, and Corruption. American Economic Review 89: 982-993.

Adserà A., Boix C. and Payne M. (2003) Are You Being Served? Political Accountability and Quality of Government. Journal of Law Economics \& Organization 19: 445-490.

Andersen R. and Curtis J. (2012) The polarizing effect of economic inequality on class identification: evidence from 44 countries. Research in Social Stratification and Mobility 30: 129-141.

Aslaksen S. (2007) Corruption and Oil: Evidence from Panel Data. Department of Economics, University of Oslo, Norway. 
Beck T., Clarke G., Groff A., Keefer P. and Walsh P. (2010) Database of Political Institutions: Updated December 2010, World Bank. http://econ.worldbank.org/WBSITE/EXTERNAL/ EXTDEC/EXTRESEARCH/0,contentMDK:20649465 pagePK:64214825 piPK:64214943 theSitePK:469382,00.html (accessed 9 December 2009).

Beck N., Katz J. N. and Tucker R. (1998) Taking Time Seriously: Time-Series-Cross-Section Analysis With a Binary Dependent Variable. American Journal of Political Science 42: 1260-1288.

Berry W. D., Golder M. and Milton D. (2012) Improving Tests of Theories Positing Interactions. Journal of Politics 74: 653-671.

Bhattacharyya S. and Hodler R. (2010) Natural Resources, Democracy and Corruption. European Economic Review 54: 608-621.

Brambor T., Clark W. R. and Golder M. (2006) Understanding Interaction Models. Improving Empirical Analysis. Political Analysis 14: 63-82.

Brunetti A. and Weder B. (2003) A Free Press is Bad News for Corruption. Journal of Public Economics 87: 1801-1824.

Bueno de Mesquita B., Morrow J. D. et al. (2002) Political Institutions, Policy Choice and the Survival of Leaders. British Journal of Political Science 32: 559-590.

Bueno de Mesquita B., Smith A. et al. (2003) The Logic of Political Survival. Cambridge, MA: MIT Press.

Camaj L. (2012) The Media's Role in Fighting Corruption: Media Effects on Governmental Accountability. International Journal of Press/Politics 18: 21-42.

Chang E. C. and Golden M. A. (2007) Electoral Systems, District Magnitude and Corruption. British Journal of Political Science 37: 115-137.

(2010) Sources of Corruption in Authoritarian Regimes. Social Science Quarterly 91: 1-20.

Chang E. C., Golden M. A. and Hill S. J. (2010) Legislative Malfeasance and Political Accountability. World Politics 62: 177-220.

Chatterjee S. and Roychoudhury S. M. (2013) Institutions, Democracy and "Corruption" in India: Examining Potency and Performance. Japanese Journal of Political Science 14: 395-419.

Costas-Peréz E., Solé-Ollé A. and Sorribas-Navarro P. (2012) Corruption Scandals, Voter Information, and Accountability. European Journal of Political Economy 28: 469-484.

Dollar D., Fisman R. and Gatti R. (2001) Are Women Really the "fairer" Sex? Corruption and Women in Government. Journal of Economic Behavior \& Organization 46: 423-429.

Downs A. (1957) An Economic Theory of Democracy. New York: Harper and Row.

Elbhanasawy N. G. and Revier C. F. (2012) The Determinants of Corruption: Cross-CountryPanel-Data Analysis. Developing Economies 50: 311-333.

Ferez C. and Finan F. (2008) Exposing Corrupt Politicians. The Effects of Brazil's Publicly Released Audits On Electoral Outcomes. Quarterly Journal of Economics 123: 703-745.

Fisman R. and Gatti R. (2002a) Decentralization and Corruption: Evidence Across Countries. Journal of Public Economics 83: 325-345.

— (2002b) Decentralization and Corruption: Evidence from U.S Federal Transfer Programs. Public Choice 113: 25-35.

Fritz V. (2007) Democratisation and Corruption in Mongolia. Public Administration and Development 27: 191-203.

Gardiner J. A. (2007) Defining Corruption. In Heidenheimer A. J. and Johnston. M. (eds.), Political Corruption: Concepts \& Contexts, Chapter 2, 3rd ed. New Brunswick, NJ: Transaction Publishers, 25-40.

Gerring J. and Thacker S. C. (2004) Political Institutions and Corruption: The Role of Unitarism and Parliamentarism. British Journal of Political Science 34: 295-330.

(2005) Do Neoliberal Policies Deter Political Corruption? International Organization 59: 233-254. 
Gokcekus O. (2008) Is It Protestant Tradition or Current Protestant Population that Affects Corruption? Economics Letters 99: 59-62.

Hosmer D. W. and Lemeshow S. (2000) Applied Logistic Regression, 2nd ed. New York: Wiley. Husted B. W. (1999) Wealth, Culture, and Corruption. Journal of International Business Studies 30: 339-359.

Kaufman D., Kray A. and Mastruzzi M. (2009) Governance Matters VIII: Aggregate and Individual Governance Indicators 1996-2008. Policy Research Working Paper No. 4978, Washington, DC, USA.

Knack S. (2007) Measuring Corruption: A Critique of Indicators in Eastern Europe and Central Asia. Journal of Public Policy 27: 255-291.

Kolstad I. and Søreide T. (2009) Corruption in Natural Resource Management: Implications for Policy Makers. Resources Policy 34: 214-226.

Kunicová J. and Rose-Ackerman S. (2005) Electoral Rules and Constitutional Structures as Constraints on Corruption. British Journal of Political Science 35: 573-606.

La Porta R. et al. (1999) The Quality of Government. Journal of Law Economics \& Organization 15: 222-279.

Lederman D., Loayza N. V. and Soares R. R. (2005) Accountability and Corruption: Political Institutions Matter. Economics \& Politics 17: 1-35.

Lindstedt C. and Naurin D. (2010) Transparency is Not Enough: Making Transparency Effective in Reducing Corruption. International Political Science Review 31: 301-322.

Loayza N., Rigolini J. and Llorente G. (2012) Do Middle Classes Bring About Institutional Reforms? Economics Letters 166: 440-444.

Long J. S. and Freese J. (2006) Regression Models for Categorical Dependent Variables Using Stata, 2nd ed. College Station, TX: Stata Press.

Manzetti L. and Wilson C. J. (2007) Why Do Corrupt Governments Maintain Public Support? Comparative Political Studies 40: 949-970.

Maoz Z. and Henderson E. A. (2013) The World Religion Dataset, 1945-2010: Logic, Estimates, and Trends. International Interactions 39: 265-291.

Montinola G. R. and Jackman R. W. (2002) Sources of Corruption: A Cross-Country Study. British Journal of Political Science 32: 147-170.

Mungiu-Pippidi A. (2013) Becoming Denmark: Historical Paths to Control of Corruption. American Political Science Association APSA, Annual Conference, http://papers.ssrn.com/ sol3/papers.cfm?abstract_id=2301329 (accessed 16 December 2014).

Neudorfer N. S. (forthcoming) Gender and Graft: A Political Economy Argument About the Influence of Working Women on Political Corruption. Journal of Women Politics \& Policy.

Pavcnik N. (2003) What Explains Skill Upgrading in Less Developed Countries? Journal of Development Economics 71: 311-328.

Pellegata A. (2013) Constraining Political Corruption: An Empirical Analysis of the Impact of Democracy. Democratization 20: 1195-1218.

Persson T., Tabellini G. and Trebbi F. (2003) Electoral Rules and Corruption. Journal of the European Economic Association 1: 958-989.

Plümper T. and Neumayer E. (2006) The Unequal Burden of War: The Effect of Armed Conflict on the Gender Gap in Life Expectancy. International Organization 60: 723-754.

Polity IV Project (2009) Polity IV Project. Political Regime Characteristics and Transitions, 18002010. http://www.systemicpeace.org/polity/polity4.htm (accessed 30 November 2012).

PRS Group (2012) The Political Risk Rating. http://www.prsgroup.com/ICRG_Methodology. aspx\#PolRiskRating (accessed 30 November 2012).

Rose-Ackerman S. (2006) Introduction and Overview. In Rose-Ackerman. S. (ed.), International Handbook on the Economics of Corruption. Cheltenham, UK: Edward Elgar Publishing Limited xiv-xxxviii. 
Sala-i-Martin X. X. (1997) I Just Ran Two Million Regressions. American Economic Review 87: $178-183$

Sandholtz W. and Koetzle W. (2000) Accounting for Corruption: Economic Structure, Democracy, and Trade. International Studies Quarterly 44: 31-50.

Schudel C. J. W. (2008) Corruption and Bilateral Aid: A Dyadic Approach. Journal of Conflict Resolution 52: 507-526.

Serra D. (2006) Empirical Determinants of Corruption: A Sensitivity Analysis. Public Choice 126: $225-256$.

Shaxson N. (2007) Oil, Corruption and the Resource Curse. International Affairs 83: 1123-1140.

de Soysa I. and Neumayer E. (2007) Resource Wealth and the Risk of Civil War Onset: Results From a New Dataset of Natural Resource Rents, 1970-1999. Conflict Management and Peace Science 24: 201-218.

Sung H.-E. (2003) Fairer Sex or Fairer System? Gender and Corruption Revisited. Social Forces 82: 703-723.

Swamy A. et al. (2001) Gender and Corruption. Journal of Development Economics 64: 25-55.

Tanzi V. (1998) Corruption Around the World: Causes, Consequences, Scope, and Cures. IMF Staff Papers 45: 559-594.

Tavits M. (2007) Clarity of Responsibility and Corruption. American Journal of Political Science 51: 218-229.

- (2010) Why Do People Engage in Corruption? The Case of Estonia. Social Forces 88: 1257-1279.

Treisman D. (2000) The Causes of Corruption: A Cross-National Study. Journal of Public Economics 76: 399-457.

- (2007) What Have We Learned About the Causes of Corruption from Ten Years of Cross-National Empirical Research? Annual Review of Political Science 10: 211-244.

Uslaner E. M. and Rothstein B. (2012) The Roots of Corruption: Mass education, economic inequality and state building. Working Paper. http://www.gvpt.umd.edu/uslaner/historicalrootscorruptionoctober2012.doc (accessed 27 March 2014).

van Veldhuizen R. (2013) The Influence of Wages on Public Officials' Corruptibility: A Laboratory Investigation. Journal of Economic Psychology 39: 314-356.

Wooldridge J. (2008) Introductory Econometrics. A Modern Approach (with Economic Applications, Data Sets, Student Solutions Manual Printed Access Card), 4th ed. Mason, $\mathrm{OH}$ : South Western Cengage Learning.

World Bank (WB) (2013a) Adjusted Savings: Energy Depletion (\% of GNI). World Bank. http:// data.worldbank.org/indicator/NY.ADJ.DNGY.GN.ZS (accessed 22 July 2013).

(2013b) Imports of Goods and Services (\% of GDP). World Bank. http://data.worldbank. org/indicator/NE.IMP.GNFS.ZS (accessed 22 July 2013).

(2013c) Trade (\% of GDP).World Bank. http://data.worldbank.org/indicator/NE.TRD. GNFS.ZS (accessed 22 July 2013).

Xin X. and Rudel T. K. (2004) The Context for Political Corruption: A Cross-National Analysis. Social Science Quarterly 85: 294-309.

You J.-S. and Khagram S. (2004) Inequality and Corruption. KSG Faculty Research Working Papers Series, RWP04-001.

- (2005) A Comparative Study of Inequality and Corruption. American Sociological Review 70: 136-157.

Zechmeister E. J. and Zizumbo-Colunga D. (2013) The Varying Political Toll of Concerns About Corruption in Good Versus Bad Economic Times. Comparative Political Studies 46: 1190-1218. 


\section{Appendix}

Table A.1. Descriptive statistics for the variables

\begin{tabular}{lcrccc}
\hline \hline Variable & Observations & Mean & SD & Minimum & Maximum \\
\hline ICRG corruption & 3,255 & 3.00 & 1.40 & 0 & 6 \\
GDP per capita (by 1,000 Dollar) & 4,331 & 5.56 & 8.52 & 0.06 & 54.48 \\
Democracy & 4,176 & 5.68 & 3.68 & 0 & 10 \\
Democracy $\times$ GDP per capita & 3,777 & 44.23 & 78.00 & 0 & 424.50 \\
Presidential system & 3,795 & 0.67 & 0.47 & 0 & 1 \\
PR-system & 2,729 & 0.59 & 0.49 & 0 & 1 \\
Energy dependence as percentage & 4,051 & 6.24 & 14.97 & 0 & 206.86 \\
$\quad$ & & & & & \\
of GNI & 4,604 & 38.79 & 9.00 & 5.05 & 54.18 \\
Momen percentage labour force & 2,663 & 2.76 & 4.38 & 0 & 117.39 \\
Prilitary spending & 9,683 & 0.12 & 0.21 & 0 & 0.99 \\
Government tradition & 4,065 & 16.32 & 6.76 & 1.38 & 76.22 \\
Corruption years & 3,254 & 4.38 & 4.49 & 0 & 24 \\
_spline1 & 3,254 & -85.75 & 155.94 & $-1,081$ & 0 \\
_spline2 & 3,254 & -196.82 & 395.26 & $-2,835$ & 0 \\
spline3 & 3,254 & -263.48 & 595.64 & $-4,536$ & 0 \\
\hline \hline
\end{tabular}

$I C R G=$ International Country Risk Guide. 